\title{
Histology and lectin histochemistry in the vomeronasal organ of Korean native cattle, Bos taurus coreanae
}

\author{
Sungwoong Jang, Bohye Kim, Joong-Sun Kim and Changjong Moon* \\ Department of Veterinary Anatomy and Animal Behavior, College of Veterinary Medicine and BK21 FOUR program, \\ Chonnam National University, Gwangju 61186, Korea
}

Received December 10, 2021

Revised December 13, 2021

Accepted December 14, 2021

\section{*Correspondence}

Changjong Moon

E-mail:moonc@chonnam.ac.kr

Author's Position and Orcid no. Jang S, MS, PhD candidate,

https://orcid.org/0000-0003-4537-3049

Kim B, PhD candidate,

https://orcid.org/0000-0002-0970-1079

Kim JS, Professor,

https://orcid.org/0000-0003-2180-4860

Moon C, Professor,

https://orcid.org/0000-0003-2451-0374

\begin{abstract}
The vomeronasal organ (VNO) is critical for reproduction and social behavior in ruminants, including cattle. The present study examined the structure of the VNO and its epithelial cells in neonatal and adult Korean native cattle (Hanwoo), Bos taurus coreanae, using immunohistochemistry and lectin histochemistry. Histologically, the VNO comprised two types of epithelia: medial vomeronasal sensory (VSE) and lateral vomeronasal non-sensory epithelia (VNSE). Numerous blood vessels and nerve bundles were observed within the vomeronasal cartilage encased lamina propria. Immunohistochemistry revealed high expression level of protein gene product9.5 and moderate expression level of olfactory marker protein in the neuroreceptor cells of the VSE and occasionally in some ciliated cells of the VNSE in both neonates and adults. The properties of the glycoconjugates in the VNO were investigated using 21 lectins, most of which were expressed at varied intensities in the VSE and VNSE, as well as in the lamina propria. Several lectins exhibited variations in their intensities and localization between neonatal and adult VNOs. This study is the first descriptive lectin histochemical examination of the VNO of Korean native cattle with a focus on lectin histochemistry, confirming that the VNO of Korean native cattle is differentiated during postnatal development.
\end{abstract}

Keywords: immunohistochemistry, Korean native cattle (Hanwoo), lectin histochemistry, postnatal development, vomeronasal organ

\section{INTRODUCTION}

Olfaction, a critical physiological function for mammalian life, is mediated by two different nasal cavity organs: the main olfactory epithelium and the vomeronasal organ (VNO) (Kelliher, 2007). Both organs share some characteristics, such as detecting same chemosensory cues, but also exhibit major variances with respect to neuron type, basic receptor protein structure, and signal transduc- tion (Firestein, 2001). The main olfactory epithelium is a component of the olfactory sensory system that passes along smell sensations to the brain. It utilizes the cilia of the sensory epithelium to capture odors and transmits the odor information to the main olfactory bulb (Lledo et al., 2005). The second organ, the VNO, is a tubular structure located bilaterally at the base of the nasal septum and is more closely associated with the perception of nonvolatile organic chemicals, such as pheromones. An indi- 
vidual animal may secrete these chemicals, to be detected by another individual; the information gathered by the latter is transferred to the accessory olfactory bulb, which triggers the occurrence of specific reproductive behaviors (Taniguchi and Mikami, 1985; Martín-Sánchez et al., 2015).

In animals, the VNO is composed of cartilage and soft tissue and comprises a lumen, vessels, glands and nerve bundles. The vomeronasal duct is covered medially and laterally by two types of epithelia: vomeronasal sensory (VSE) and vomeronasal non-sensory epithelia (VNSE) (Halpern, 1987). The VSE is a pseudostratified epithelium composed of vomeronasal receptor neurons, basal cells, and supporting cells, whereas the VNSE is typically situated on the opposite side of the vomeronasal lumen and mimics the respiratory epithelium (Zancanaro, 2014). Both protein gene product9.5 (PGP9.5; neuron and neuroendocrine cell marker) and olfactory marker protein (OMP; a mature olfactory receptor cell marker) are expressed in VNO receptor neurons (Thompson et al., 1983; Buiakova et al., 1994). Previous studies have shown that PGP9.5 and OMP are expressed in most VNO receptor cells of the VSE and in some isolated cells of the VNSE in various mammals, including mice (Lin et al., 2008), goats (Yang et al., 2021), camels (Ibrahim et al., 2015), horses (Lee et al., 2016), non-human primates (Dennis et al., 2004), and humans (Johnson et al., 1995).

Although it was previously believed that the rodent VNO was representative of the mammalian vomeronasal system, current histology and behavioral research both indicate that rodent VNO functions are not identical to those described in other mammals (Silva and Antunes, 2017). Among ruminants, cattle have a well-developed VNO that is capable of functioning similarly to that of rodents in terms of the pump mechanism, but they exhibit significant differences in the morphological and functional properties of the vomeronasal duct (Salazar et al., 2008). Additionally, various studies have been conducted on the VNO in cattle; however, most studies have concentrated on the structural characteristics, particularly in adults (Taniguchi and Mikami, 1985; Adams, 1986; Salazar et al., 1995; Salazar et al., 1997; Salazar et al., 2008).

Glycoconjugates are involved in a variety of biological activities, including cellular adhesion, embryonic development, signal transduction, immunomodulation, and inflammation (Gorelik et al., 2001; Sharon and Lis, 2004;
Wormald and Sharon, 2004; Lam and Ng, 2011). Their terminal carbohydrates influence the perception of odorants and are critical for chemoreception in the VNO (Plendl and Sinowatz, 1998). In chemosensory systems, lectin histochemistry has commonly been utilized to discriminate terminal carbohydrate residues (Salazar et al., 2001). The carbohydrate (lectin-binding) moiety is expressed in the VNOs of various mammals, including rats (Mendoza and Kuhnel, 1991), mice (Barrios et al., 2014), rabbits (Villamayor et al., 2018), foxes (Ortiz-Leal et al., 2020), marmosets (Nakajima et al., 1998), goats (Yang et al., 2021), pigs (Salazar et al., 2004; Park et al., 2012), sheep (Ibrahim et al., 2014), roe deer (Park et al., 2014), and horses (Lee et al., 2016). However, little is known about the expression of PGP9.5, OMP, and diverse lectin-binding carbohydrates in various cell types and structures in the VNO of cattle even though the morphological features of the cattle VNO are well-characterized (Taniguchi and Mikami, 1985; Adams, 1986; Salazar et al., 1995; Salazar et al., 1997; Salazar et al., 2008).

In the present study, we examined the histological features and lectin histochemistry of the VNO in Korean native cattle (Hanwoo), and identified traits associated with maturation by comparing newborn calves and adult cows. This is the first time, to our knowledge, that lectins have been examined to offer a thorough histochemical description of the bovine VNO.

\section{MATERIALS AND METHODS}

\section{Tissue preparation}

Three adult VNOs from Korean native cattle (Hanwoo, Bos taurus coreanae; 2.5 years old) were obtained from a local slaughterhouse in Chungcheongbuk-do, South Korea. Three VNOs of newborn calves (1-3 days old) were obtained postmortem. All animals used in the present study were female, and based on gross and histological findings of the nasal cavity, they did not have any underlying diseases related to the respiratory system. All applicable international, national, and/or institutional guidelines for the care and use of animals were strictly followed. All animal sample collection protocols complied with the current laws of South Korea.

\section{Histological examination}

The VNOs were removed immediately after death and 
fixed for one week in $10 \%$ buffered formalin. After fixation, the VNOs were decalcified using sodium citrateformic acid solution with agitation. The decalcification process was halted when a needle easily pierced the bone without exerting any force. Subsequently, samples were rinsed for $24 \mathrm{~h}$ in running tap water, subjected to standard dehydration, embedded in paraffin, and sectioned into $4-\mu \mathrm{m}$ thick pieces. Following deparaffinization, the sections were stained with hematoxylin and eosin, periodic acid-Schiff (PAS), and Alcian blue (pH 1.0 and 2.5).

\section{Immunohistochemistry}

The sections were heated for $1 \mathrm{~h}$ at $90^{\circ} \mathrm{C}$ in citrate buffer (0.01 M, pH 6.0) to retrieve antigens, and then ex- posed for 20 min to $0.3 \%$ hydrogen peroxide in distilled water to block endogenous peroxidase activity. To block non-specific binding, the sections were incubated for 1 $\mathrm{h}$ in normal horse or goat serum (Vectastain Elite ABC kit; Vector Laboratories, Burlingame, CA, USA), following by overnight incubation at $4^{\circ} \mathrm{C}$ with a $1: 5000$ dilution of mouse monoclonal anti-PGP9.5 (ab72911; Abcam, Cambridge, UK) or a 1:50 dilution of rabbit monoclonal antiOMP (ab183947; Abcam) antibodies overnight. The sections were then incubated with biotinylated horse antimouse or goat anti-rabbit IgG antibodies (Vectastain Elite $A B C$ kit). The avidin-biotin peroxidase complex (Vectastain Elite $\mathrm{ABC}$ kit) was used for immunoreactivity. A diaminobenzidine substrate kit (DAB Substrate Kit SK-4100;

Table 1. Summary of the lectins used, including source, sugar specificity, concentration, and inhibitor

\begin{tabular}{|c|c|c|c|c|}
\hline Lectin abbreviations & Source & Sugar specificity ${ }^{a}$ & $\begin{array}{l}\text { Concentration } \\
(\mu \mathrm{g} / \mathrm{mL})\end{array}$ & Inhibitor or eluting sugar ${ }^{\mathrm{b}}$ \\
\hline \multicolumn{5}{|c|}{$\mathrm{N}$-acetylglucosamine-binding lectins } \\
\hline s-WGA & Succinylated-wheat germ agglutinin & GlcNAc & $1.0 \times 10^{-2}$ & $0.2 \mathrm{M} \mathrm{GlcNAc}$ \\
\hline WGA & Wheat germ agglutinin & GlcNAc NeuAc, SA & $1.0 \times 10^{-2}$ & $0.2 \mathrm{M} \mathrm{GlcNAc}$ \\
\hline $\mathrm{BSL}-\|$ & Bandeiraea simplicifolia lectin ॥ & $\alpha$ or $\beta$ GlcNAc & $4.0 \times 10^{-3}$ & $0.2 \mathrm{M} \mathrm{GlcNAc}$ \\
\hline DSL & Datura stramonium lectin & $(\mathrm{GlcNAc})_{2-4}$ & $2.0 \times 10^{-2}$ & $0.5 \mathrm{M}$ chitin hydrolysate \\
\hline LEL & Lycopersicon esculentum lectin & $(\mathrm{GlcNAc})_{2-4}$ & $1.0 \times 10^{-2}$ & $0.5 \mathrm{M}$ chitin hydrolysate \\
\hline STL & Solanum tuberosum lectin & $(\mathrm{GlcNAc})_{2-4}$ & $1.0 \times 10^{-2}$ & $0.5 \mathrm{M}$ chitin hydrolysate \\
\hline \multicolumn{5}{|c|}{ Mannose-binding lectins } \\
\hline ConA & Canavalia ensiformis (concanavalin A) & aMan, $\alpha \mathrm{Glc}, 4 \mathrm{GlcNAc}$ & $3.3 \times 10^{-3}$ & $0.2 \mathrm{M}$ Me $\alpha \mathrm{Man} / 0.2 \mathrm{M}$ Me $\alpha \mathrm{Glc}$ \\
\hline LCA & Lens culinaris agglutinin & $\alpha$ Man, $\alpha \mathrm{Glc}, 4(\mathrm{Fuc} \alpha 1,6) \mathrm{GlcNAc}$ & $4.0 \times 10^{-3}$ & $0.2 \mathrm{M} \mathrm{Me} \alpha \mathrm{Man} / 0.2 \mathrm{M} \mathrm{Me} \alpha \mathrm{Glc}$ \\
\hline PSA & Pisum sativum agglutinin & aMan, $\alpha \mathrm{Glc}, 4(\mathrm{Fuc} \alpha 1,6) \mathrm{GlcNAc}$ & $4.0 \times 10^{-3}$ & $0.2 \mathrm{M}$ Me $\alpha \operatorname{Man} / 0.2 \mathrm{M} \mathrm{Me} \alpha \mathrm{Gl} \mathrm{c}$ \\
\hline \multicolumn{5}{|c|}{ Galactose/N-acetylgalactosamine-binding lectins } \\
\hline $\mathrm{RCA}_{120}$ & Ricinus communis agglutinin I & Gal & $2.0 \times 10^{-3}$ & $0.2 \mathrm{M}$ lactose \\
\hline $\mathrm{BSL}-1$ & Bandeiraea simplicifolia lectin I & $\alpha \mathrm{Gal}, \alpha \mathrm{GalNAc}$ & $4.0 \times 10^{-3}$ & $0.2 \mathrm{M} \mathrm{GlcNAc}$ \\
\hline VA & Vicia villosa agglutinin & GalNAc & $4.0 \times 10^{-3}$ & 0.2 M GlcNAc \\
\hline DBA & Dolichos biflorus agglutinin & $\alpha$ GalNAc & $1.0 \times 10^{-2}$ & $0.2 \mathrm{M} \mathrm{GlcNAc}$ \\
\hline SBA & Glycine maxi (soybean agglutinin) & $\alpha>\beta$ GalNAc & $1.0 \times 10^{-2}$ & $0.2 \mathrm{M}$ GlcNAc \\
\hline SJA & Sophora japonica agglutinin & $\beta$ GalNAc & $2.0 \times 10^{-2}$ & $0.2 \mathrm{M} \mathrm{GlcNAc}$ \\
\hline Jacalin & Artocarpus integrifolia (Jacalin) & Galß3GalNAc & $5.0 \times 10^{-4}$ & $0.2 \mathrm{M}$ melibiose \\
\hline PNA & Arachis hypogaea (peanut) agglutinin & Galp3GalNAc & $4.0 \times 10^{-3}$ & $0.2 \mathrm{M} \beta \mathrm{Gal}$ \\
\hline $\mathrm{ECL}$ & Erythrina cristagalli lectin & Galß3GalNAc & $2.0 \times 10^{-2}$ & $0.2 \mathrm{M}$ lactose \\
\hline \multicolumn{5}{|c|}{ Complex type $\mathrm{N}$-glycans (complex oligosaccharides)-binding lectins } \\
\hline PHA-E & Phaseolus vulgaris $\mathrm{E}$ & $\begin{array}{c}\text { Gal } \beta 3 \text { GalNAc } \beta 2 \text { Man } \alpha 6 \text { (GlcNA } \\
\text { c } \beta 4)(\text { GlcNAc } \beta 4 \text { Man } \alpha \text { 3) Man } \beta 4\end{array}$ & $5.0 \times 10^{-3}$ & $0.1 \mathrm{M}$ acetic acid \\
\hline $\mathrm{PHA}-\mathrm{L}$ & Phaseolus vulgaris L & $\begin{array}{l}\text { Gal } \beta 4 \text { GIcNAc } \beta 6 \text { (GluNAc } \beta 2 \text { Man } \\
\alpha 3 \text { ) Man } \alpha 3\end{array}$ & $2.5 \times 10^{-3}$ & $0.1 \mathrm{M}$ acetic acid \\
\hline \multicolumn{5}{|l|}{ Fucose-binding lectin } \\
\hline UEA- I & Ulex europaeus I & $\alpha$ Fuc & $2.0 \times 10^{-2}$ & $0.1 \mathrm{M} \mathrm{L-fucose}$ \\
\hline
\end{tabular}

${ }^{a}$ Acronyms are explained in the text; GlcNAc, N-acetylgalactosamine; NeuAc, N-acetylneuraminic acid; SA, sialic acid; GlcNAc, N-acetylglucosamine; gal, galactose; glc, glucose; Fuc, fucose.

${ }^{\text {b}}$ The lectin specificities, including sources, preferred sugar specificity, and inhibitors, were modified according to a previous study (Kang et al., 2016). 
Vector Laboratories) was used to develop the peroxidase reaction. Prior to mounting, the sections were counterstained with hematoxylin.

\section{Lectin histochemistry}

Lectin screening kits (I-III) were purchased from Vector Laboratories (Burlingame, CA, USA). Table 1 shows the list of lectins used in the present study and classified into Nacetylglucosamine, mannose, galactose/ $\mathrm{N}$-acetylgalactosamine, complex type $\mathrm{N}$-glycan, and fucose-binding lectin groups, according to the binding specificities and inhibitory sugars. The following sugars were obtained from Sigma-Aldrich (St. Louis, MO, USA) and Vector Laboratories and used for competitive inhibition (Table 1): $\alpha$-methyl mannoside/ $\alpha$-methyl glucoside (Sigma-Aldrich), $\beta$-dgalactose (Sigma-Aldrich), lactose (Gal $\beta 1$, 4Glc; Sigma-Aldrich), melibiose (Gal $\alpha 1,6$ Glc; Sigma-Aldrich), N-acetyl- d-galactosamine ( $\alpha$-d-GalNAc; Sigma-Aldrich), N-acetyld-glucosamine ( $\beta$-D-GlcNAc; Sigma-Aldrich), and chitin hydrolysate (Vector Laboratories).

The sections were incubated for $30 \mathrm{~min}$ in $0.3 \%$ hydrogen peroxide in methanol to block endogenous peroxidase activity. After washing the slides with phosphate-buffered saline (PBS), they were treated with $1 \%$ bovine serum albumin in PBS to block non-specific activity. The sections were incubated overnight at $4{ }^{\circ} \mathrm{C}$ with each lectin using the $\mathrm{ABC}$ methods. Following incubation, the sections were washed three times with PBS. A diaminobenzidine substrate kit (DAB Substrate Kit SK-4100; Vector Laboratories) was used to generate the signals; sections were counterstained with hematoxylin prior to mounting. Negative controls for lectin histochemistry were established by preincubating the lectins with suitable inhibitors in 0.2-0.5 M Tris buffer for $1 \mathrm{~h}$ at room temperature prior to use.
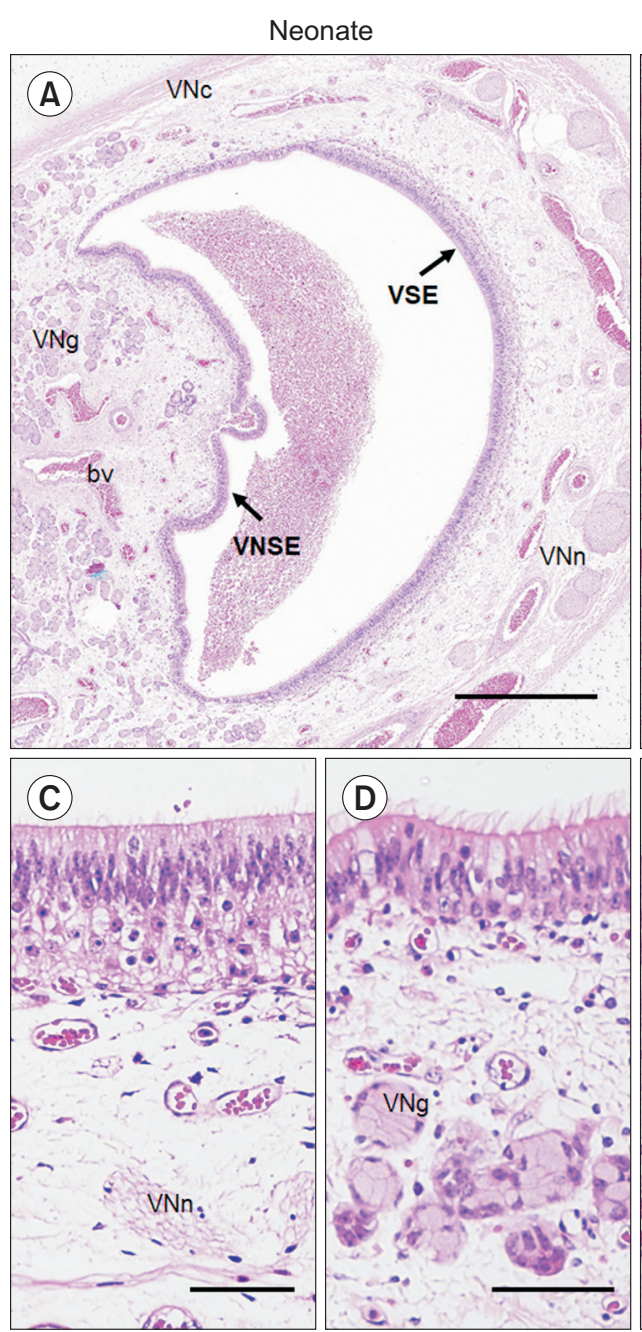

Adult
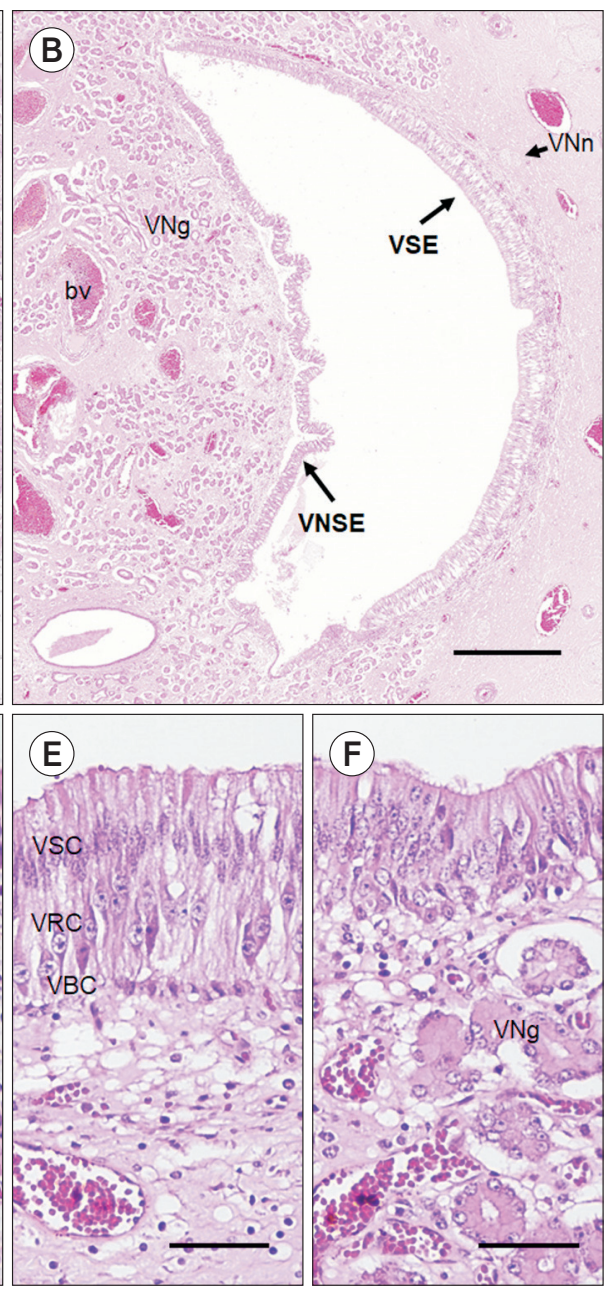

Fig. 1. Histological examination of VNOs from Korean native cattle. (A, B) Low-magnification views of the $\mathrm{VNO}$ in neonates $(A)$ and adults (B). (C, D) High-magnification views of the VSE (C) and VNSE (D) in neonates. (E, F) High-magnification views of the VSE (E) and VNSE (F) in adults. bv, blood vessels; VBC, vomeronasal basal cell; VNc, vomeronasal cartilage; VNg, vomeronasal glands; VNn, vomeronasal nerves; VNO, vomeronasal organ: VSC, vomeronasal supporting cell; VSE, vomeronasal sensory epithelium; VNSE, vomeronasal non-sensory epithelium; VRC, vomeronasal receptor cell. Hematoxylin and eosin staining. Scale bars $=500 \mu \mathrm{m}(\mathrm{A}, \mathrm{B}), 50 \mu \mathrm{m}(\mathrm{C}-$ F). 


\section{RESULTS}

\section{Histological characteristics of the VNO}

Histological features of VNOs from neonatal and adult Korean native cattle are depicted in Fig. 1. The VNO is composed of a vomeronasal capsule and a vomeronasal duct, both of which are connected to the parenchyma, which contains blood vessels, nerves, and vomeronasal glands (Fig. 1A, B). The VSE is a columnar, pseudostratified, and non-ciliated epithelium predominantly composed of three different cell types: neuroreceptor cells, supporting cells, and basal cells (Fig. 1C, E). The first two cell types are stratified, resulting in apical and basal portions. The VNSE, a pseudostratified columnar epithelium with cilia on its surface, is found in both the nasal mucosa and the respiratory epithelium of the VNO (Fig. 1D, F). It is composed of three distinct cell types: goblet cells, ciliated cells, and basal cells. VNOs had similar histological structures between neonates and adults; however, adult VNOs were more developed than neonatal VNOs. The glandular cells in vomeronasal glands of the VNSE were positive for PAS (Fig. 2A, B) and Alcian blue staining (pH 2.5; Fig. 2C, D) at both stages.

\section{PGP9.5 and OMP immunostaining in the VNO}

The results of immunostaining to PGP9.5 and OMP in the VNOs of Korean native cattle at the neonatal and adult stages are summarized in Table 2. PGP9.5 was

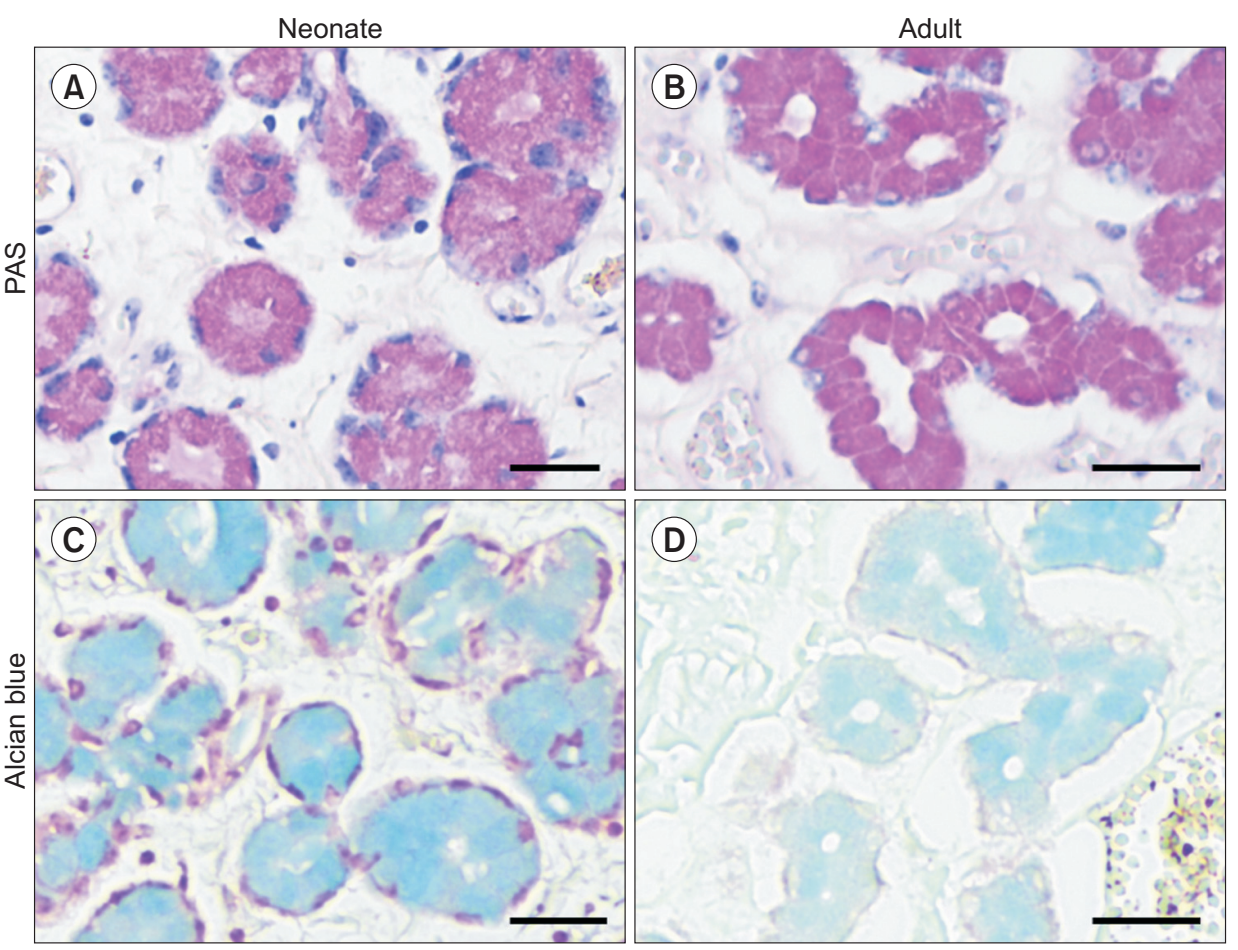

Fig. 2. Histological features of vomeronasal glands in Korean native cattle. (A, B) Vomeronasal glands stained with periodic acid-Schiff (PAS) in neonates (A) and adults (B). (C, D) Vomeronasal glands stained with Alcian blue ( $\mathrm{pH} 2.5)$ in neonates $(\mathrm{C})$ and adults (D). Scale bars $=25 \mu \mathrm{m}$.

Table 2. Expression patterns of PGP9.5 and OMP in the vomeronasal organ (VNO) of Korean native cattle

\begin{tabular}{|c|c|c|c|c|c|c|}
\hline Antibody & Stage & \multicolumn{3}{|c|}{ VSE } & \multicolumn{2}{|c|}{ VNSE } \\
\hline PGP9.5 & Neonatesw & +++ & - & - & $t^{a}$ & - \\
\hline \multirow[t]{2}{*}{ OMP } & Neonates & ++ & - & - & $+^{\mathrm{a}}$ & - \\
\hline & Adults & ++ & - & - & $t^{a}$ & - \\
\hline
\end{tabular}

Abbreviation: PGP9.5, protein gene product9.5; OMP, olfactory marker protein; VSE, vomeronasal sensory epithelium; VNSE, vomeronasal non-sensory epithelium. Stained sections were scored as follows: -, negative; +, low intensity; ++, moderate intensity; +++, high intensity.

${ }^{\text {a }}$ Some cells are positive. 
abundantly detected in most vomeronasal receptor cells in the VSE, but not in supporting or basal cells (Fig. 3A, C). PGP9.5-positive receptor cells were located in the middle layer of the VSE with their dendrites extending to the free border. PGP9.5-positive nerve fibers and some ciliated cells were found in the VNSE, whereas basal cells were negative for PGP9.5 (Fig. 3B, D). Nerve bundles exhibited intense staining for PGP9.5 in the lamina propria of the VNO (Fig. 3A, C; asterisks).

OMP was moderately detected in the receptor cells of neonatal VSE, but its staining was more distinct in adults (Fig. 3E, G). In contrast, OMP expression was not detected in the supporting or basal cells in both neonates and adults. In the VNSE, some ciliated cells were weakly positive for OMP in the apical portion of the epithelial layer (Fig. 3G, H). The ductal epithelium of the vomeronasal glands was weakly positive for OMP in the lamina propria of the VNO (Fig. 3H).

\section{Lectin histochemistry in the VSE}

Table 3 summarizes the intensities of the 21 lectins in the VSE of Korean native cattle.

\section{1) $\mathrm{N}$-acetylglucosamine-binding lectins}

In the VSE, the free border, receptor cell, and nerve bundle showed faintly positive s-WGA staining in neonates, whereas their intensities were strongly positive in adults (Fig. 4A, B). With regards to the WGA, reactivity in adults (which showed moderate or intense staining in most cell types) was generally greater than that in neonates. For BSL-II, only the free border and receptor cells displayed faint labeling among neonates, whereas the basal cells were also faintly labeled in adults. In both neonates and adults, DSL and LEL were positively labeled in all VSE layers, and their supporting cells exhibited comparatively faint staining among the cell types (Fig. 4C, D). The labeling patterns of STL were comparable to those of DSL and LEL, but supporting cells were negative for STL in both neonates and adults (Fig. 4E, F).

\section{2) Mannose-binding lectins}

ConA was intensely labeled in the free border in the VSE, with various levels of intensity throughout the layers at both stages. The LCA and PSA reactivities in neonates were positively detected in all VSE layers except in supporting cells (Fig. 4G, I), and their intensity was greater in adults than in neonates (particularly PSA reactivity) (Fig. 4H, J).
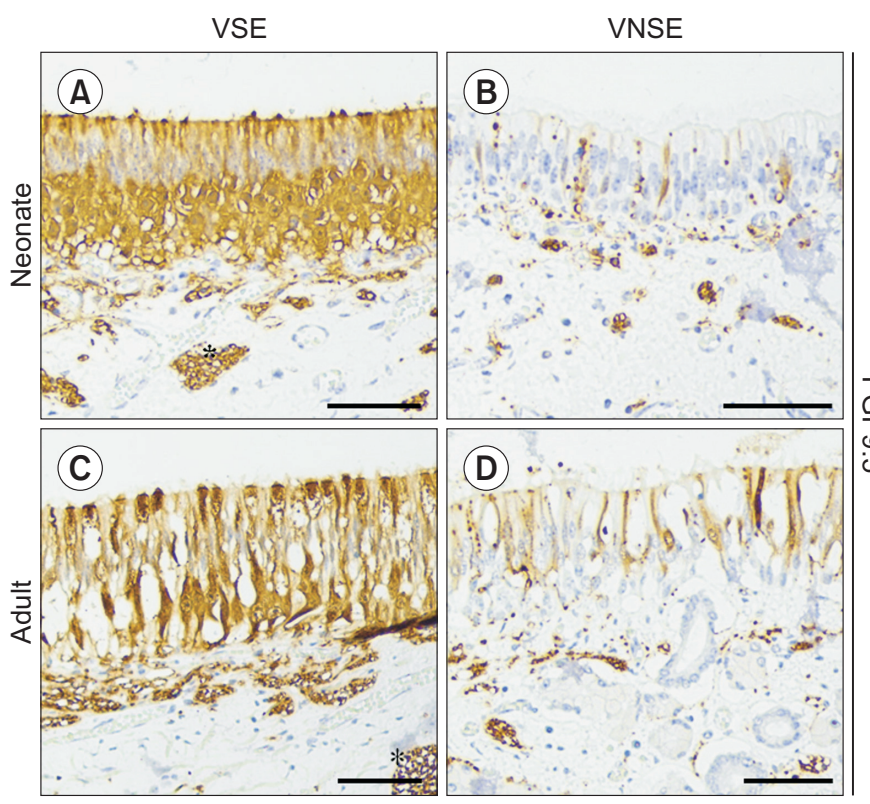
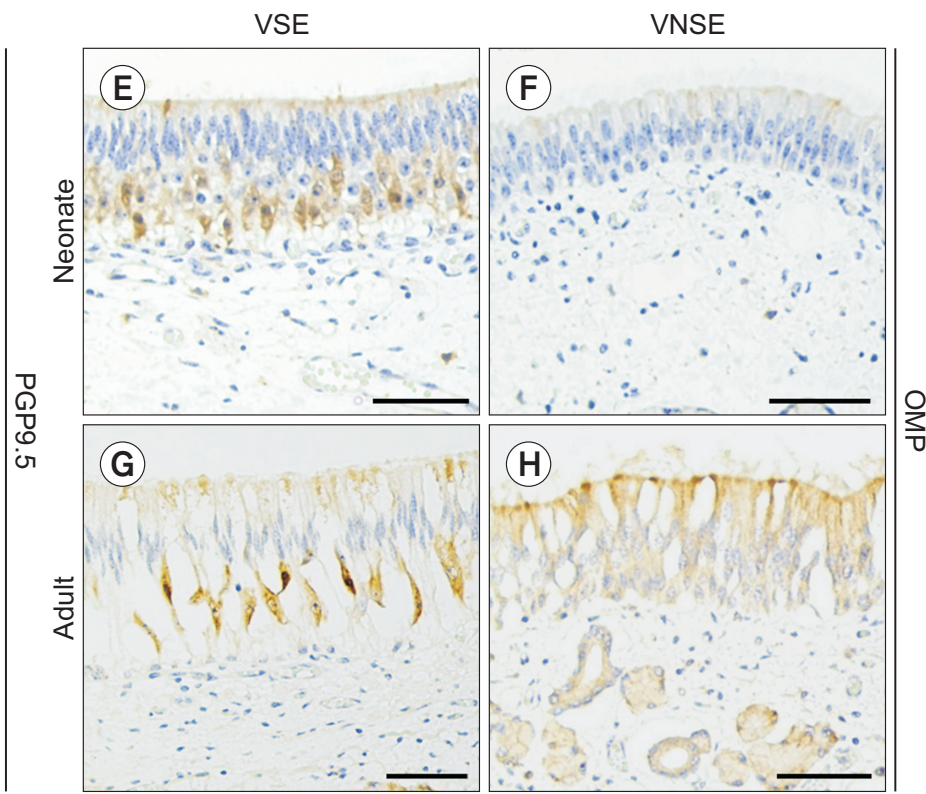

Fig. 3. Immunohistochemical staining of VNOs from Korean native cattle. (A-D) PGP9.5 is intensely labeled in receptor cells in the VSE of both neonates (A) and adults (C), and some nerve fibers and ciliated cells also showed reactions in the VNSE of neonates (B) and adults (D). PGP9.5 is also expressed in the vomeronasal nerve bundle (A, C; asterisks). (E-H) OMP is weakly labeled in the VSE of neonates (C) and adults (G), and some ciliated cells showed reactions in VNSE of neonates (D) and adults (H). Counterstained with hematoxylin. OMP, olfactory marker protein; PGP9.5, protein gene product9.5; VNSE, vomeronasal non-sensory epithelium; VSE, vomeronasal sensory epithelium. Scale bars $=50 \mu \mathrm{m}$. 
Table 3. Lectin-binding pattern in the vomeronasal sensory epithelium (VSE) of Korean native cattle

\begin{tabular}{|c|c|c|c|c|c|c|c|c|c|c|}
\hline \multirow{2}{*}{$\begin{array}{c}\text { Lectin } \\
\text { abbreviations }\end{array}$} & \multicolumn{5}{|c|}{ Neonatal structures } & \multicolumn{5}{|c|}{ Adult structures } \\
\hline & $\begin{array}{c}\text { Free } \\
\text { border }\end{array}$ & $\begin{array}{l}\text { Receptor } \\
\text { cells }\end{array}$ & $\begin{array}{l}\text { Supporting } \\
\text { cells }\end{array}$ & $\begin{array}{l}\text { Basal } \\
\text { cells }\end{array}$ & $\begin{array}{l}\text { Nerve } \\
\text { bundle }\end{array}$ & $\begin{array}{l}\text { Free } \\
\text { border }\end{array}$ & $\begin{array}{l}\text { Receptor } \\
\text { cells }\end{array}$ & $\begin{array}{l}\text { Supporting } \\
\text { cells }\end{array}$ & $\begin{array}{l}\text { Basal } \\
\text { cells }\end{array}$ & $\begin{array}{l}\text { Nerve } \\
\text { bundle }\end{array}$ \\
\hline s-WGA & + & + & - & - & + & +++ & +++ & - & + & +++ \\
\hline WGA & ++ & ++ & + & + & + & +++ & +++ & + & ++ & ++ \\
\hline LEL & ++ & ++ & + & ++ & +++ & +++ & ++ & ++ & ++ & ++ \\
\hline STL & +++ & ++ & - & ++ & +++ & +++ & +++ & - & +++ & +++ \\
\hline \multicolumn{11}{|c|}{ Mannose-binding lectins } \\
\hline ConA & +++ & + & + & + & ++ & +++ & ++ & + & + & ++ \\
\hline LCA & ++ & + & - & + & + & ++ & ++ & - & ++ & ++ \\
\hline BSL-I & ++ & ++ & - & ++ & + & ++ & ++ & - & ++ & + \\
\hline VA & ++ & ++ & - & + & + & ++ & +++ & - & + & ++ \\
\hline DBA & + & + & ++ & - & + & + & + & ++ & + & + \\
\hline SBA & ++ & ++ & - & - & + & ++ & ++ & - & + & ++ \\
\hline SJA & +++ & + & - & + & ++ & ++ & ++ & + & + & ++ \\
\hline Jacalin & ++ & ++ & + & + & + & ++ & +++ & + & + & ++ \\
\hline PNA & +++ & ++ & - & ++ & +++ & +++ & +++ & - & +++ & +++ \\
\hline $\mathrm{ECL}$ & +++ & ++ & + & ++ & +++ & +++ & +++ & ++ & ++ & +++ \\
\hline \multicolumn{11}{|c|}{ Complex type $\mathrm{N}$-glycans (complex oligosaccharides)-binding lectins } \\
\hline PHA-E & ++ & + & + & + & + & +++ & + & ++ & + & + \\
\hline
\end{tabular}

-, negative staining; +, faint staining; ++, moderate staining; +++, intense staining.

\section{3) Galactose/N-acetylgalactosamine-binding lectins}

The majority of lectins elicited a range of reactions in the free border. The adult VSE reacted more strongly than the neonatal VSE to $\mathrm{RCA}_{120}$, SJA, Jacalin, and ECL. Furthermore, VVA (Fig. 5A, B), Jacalin, PNA (Fig. 5E, F), and ECL exhibited intense staining in the free border and receptor cells. The supporting cells were labeled with RCA $_{120}$, DBA (Fig. 5C, D), SJA, Jacalin, and ECL (faint or moderate staining), and the nerve bundles were labeled with all lectins. Neonatal basal cells showed no reaction for DBA (Fig. 5C, D) or SBA, but adults had faint labeling.

\section{4) Complex type $\mathrm{N}$-glycan-binding lectins}

PHA-E and PHA-L (Fig. 5G, H) were labeled throughout all VSE layers at various intensities. The reactivity of both PHA-E and PHA-L in adults was generally greater than that in neonates, except in receptor cells (Fig. 5G, H). In the nerve bundles, the reactivity did not differ by age, but differences were seen between the two lectins, indicating extensively higher levels of PHA-L than PHA-E.

5) Fucose-binding lectin

UEA-I was highly labeled in both the free border and receptor cells in neonates and adults (Fig. 5I, J). The supporting cells showed faint UEA-I labeling in both neonates and adults. There was no reactivity in neonatal basal cells; in contrast, there was weak reactivity in those of adults.

\section{Lectin histochemistry in the VNSE}

Table 4 summarizes the intensities of the 21 lectins in the VNSE of Korean native cattle.

1) N-acetylglucosamine-binding lectins

In the free border, all lectins, except for BSL-II, elicited 

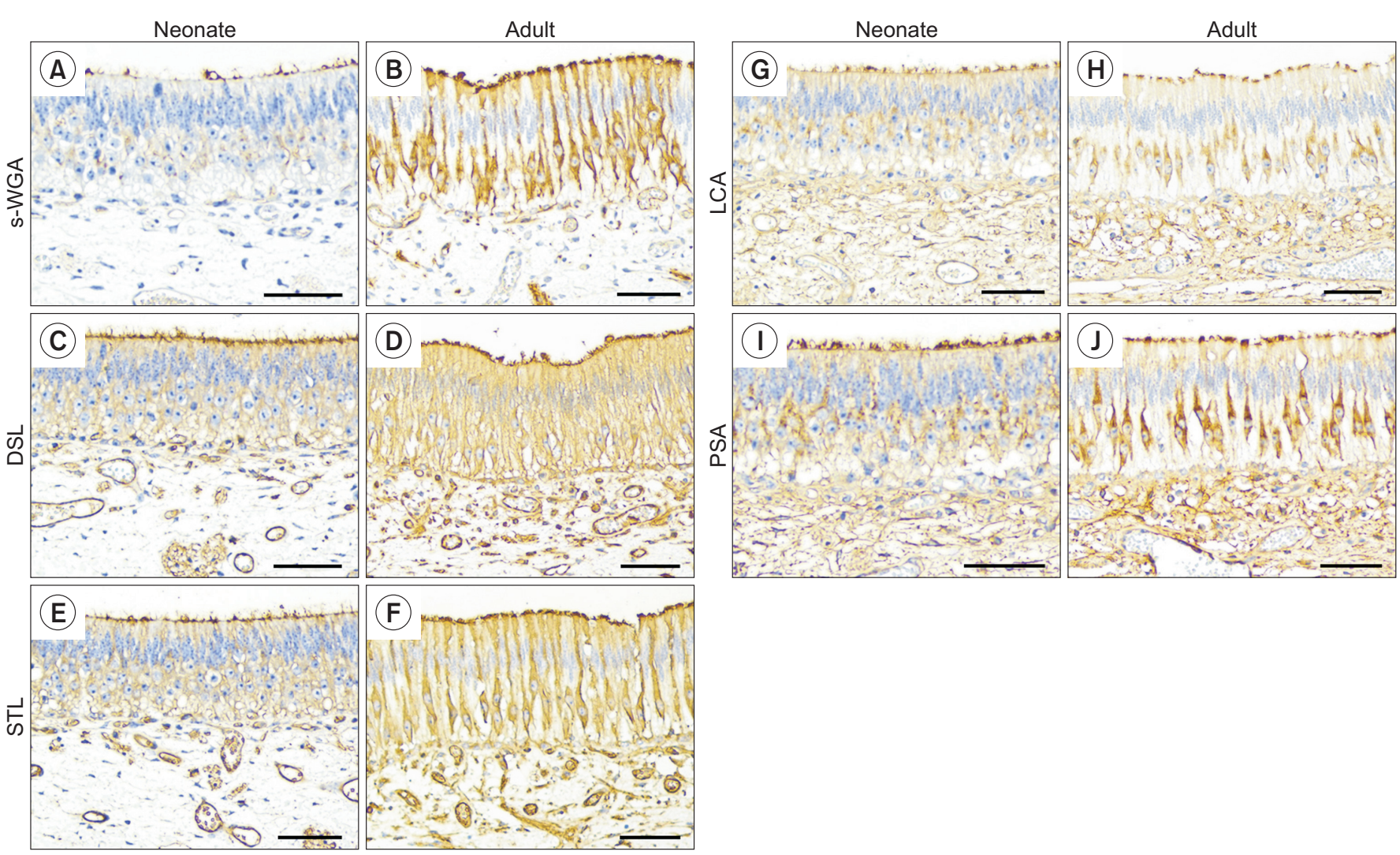

Fig. 4. Lectin histochemistry with $\mathrm{N}$-acetylglucosamine and mannose-binding lectins in the VSE of Korean native cattle. (A-F) The reactivities of $N$-acetylglucosamine-binding lectins, including S-WGA $(A, B), D S L(C, D)$, and STL (E, F) in both neonatal (A, $C, E)$ and adult VSE (B, D, F). (G-J) The reactivities of mannose-binding lectins, including LCA $(G, H)$ and PSA $(I, J)$ in both neonatal $(G, I)$ and adult VSE $(I, J)$. Counterstained with hematoxylin. DSL, Datura stramonium lectin; LCA, Lens culinaris agglutinin; PSA, Pisum sativum agglutinin: STL, Solanum tuberosum lectin; s-WGA, succinylated-wheat germ agglutinin. Scale bars $=50 \mu \mathrm{m}$.

a response with varying intensities in both neonates and adults. In the VNSE, most lectins exhibited higher intensity in adults than in neonates, except s-WGA (Fig. 6A, B). Strong reactions for DSL (Fig. 6C, D), LEL, and STL (Fig. 6E, F) in ciliated cells and s-WGA (Fig. 6A, B), WGA, LEL, and STL (Fig. 6E, F) in gland acini were observed in adults. WGA, BSL-II, LEL, and STL (Fig. 6E, F) stained more intensely in adults than in neonates in the case of goblet cells.

\section{2) Mannose-binding lectins}

ConA reacted similarly in all layers of VNSE between neonates and adults. However, neonatal ciliated cells exhibited only a faint positive reaction for LCA (Fig. 6G) and PSA (Fig. 6I), whereas adult ciliated cells showed moderate labeling. In neonates, there was no LCA reactivity in the free border, goblet cells, and basal cells (Fig. 6G), whereas weak labeling was observed in those of adults (Fig. 6H). For PSA, no reaction was detected in the free border in neonates, but a moderate reaction was observed in that of adults; likewise, goblet cells revealed stronger reactivity in adults than in neonates (Fig. 6I, J).

\section{3) Galactose/N-acetylgalactosamine-binding lectins}

Although the expression intensities of the majority of lectins, including BSL-I (Fig. 7A, B), generally showed similar patterns, some lectins had stronger expression intensities in adults than in neonates. In the free border, SJA and PNA labeling was detected at a low intensity in neonates, but at a considerable intensity in adults. In ciliated cells, VVA (Fig. 7C, D), DBA, SBA, and ECL (Fig. 7E, F) were found to have higher intensities in adults than in neonates. Additionally, ECL reacted more strongly in goblet cells and basal cells of adults than in those of neonates (Fig. 7E, F).

4) Complex type $\mathrm{N}$-glycan-binding lectins

Both PHA-E (Fig. 7G, H) and PHA-L showed similar 

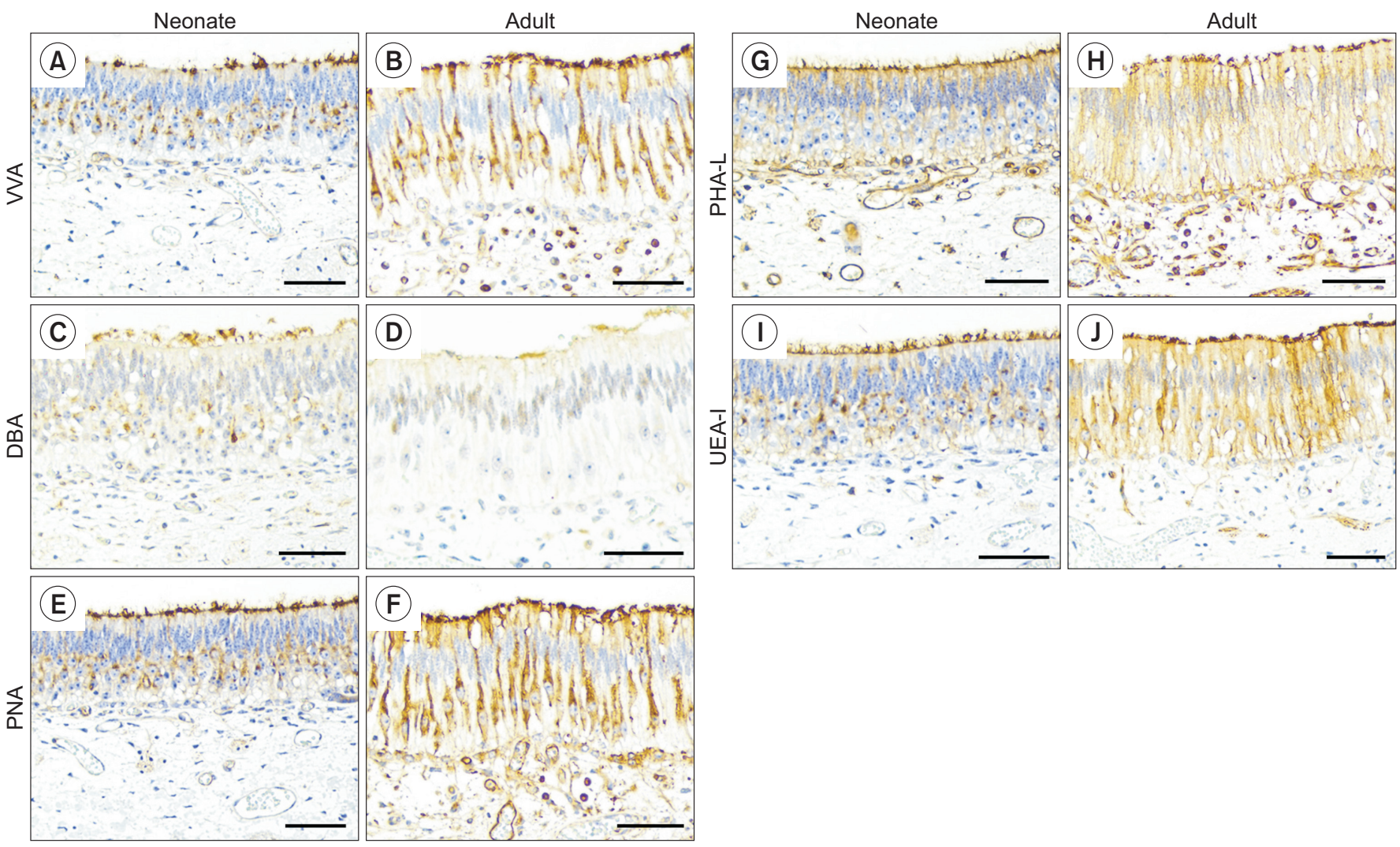

Fig. 5. Lectin histochemistry with galactose/N-acetylgalactosamine, complex type $\mathrm{N}$-glycans (complex oligosaccharides), and fucosebinding lectins in the VSE of Korean native cattle. (A-F) The reactivities of galactose/ $\mathrm{N}$-acetylgalactosamine-binding lectins, including VVA $(A, B), D B A(C, D)$, and PNA $(E, F)$ in both neonatal $(A, C, E)$ and adult VSE $(B, D, F) .(G, H)$ The reactivity of complex type N-glycans-binding lectin PHA-L in both neonatal $(G)$ and adult VSE $(H)$. I, J: The reactivity of fucose-binding lectin UEA-I in both neonatal (I) and adult VSE (J). Counterstained with hematoxylin. DBA, Dolichos biflorus agglutinin; PHL-L, Phaseolus vulgaris L; PNA, Arachis hypogaea (peanut) agglutinin; UEA-I, Ulex europaeus l; VVA, Vicia villosa agglutinin. Scale bars $=50 \mu \mathrm{m}$.

staining in the free border, ciliated cells, and basal cells of the VNSE, while PHA-L in the goblet cells and gland acini was more intensely labeled in adults than in neonates. Additionally, PHA-E produced more intense labeling in goblet cells in adults than in neonates.

\section{5) Fucose-binding lectin}

Both neonates and adults displayed moderate to strong staining for UEA-I in the free border, ciliated cells, and gland acini (Fig. 7I, J). Neonatal goblet cells had no reaction, but adult goblet cells were weakly positive. There was no reactivity for UEA-I in the basal cells of either neonatal or adult VNSE (Fig. 7I, J).

\section{DISCUSSION}

The vomeronasal systems of mammals exhibit considerable diversity in terms of their anatomical, physiological, and behavioral characteristics (Meisami and Bhatnagar, 1998; Salazar and Quinteiro, 2009). Comparative sequencing has indicated that the vomeronasal system is more diverse than the olfactory system at the genomic level (Grus and Zhang, 2004; D'Oliveira Albanus et al., 2014). From an animal evolutionary point of view, this diversity can be attributed to the different behavioral and reproductive strategies of each animal species, and the usage of pheromones (Keverne, 2005; Brennan and Zufall, 2006). Given this enormous diversity, additional morphological and functional studies of the vomeronasal system across animal species are required to understand the genetic and behavioral underpinnings of this diversity. Moreover, the anatomical and behavioral studies available suggest that VNO functions are not precisely identical between animals (Silva and Antunes, 2017).

Numerous studies have been conducted on the anatomy of the VNO in cattle (Minett, 1925; Taniguchi and Mikami, 
Table 4. Lectin-binding pattern in the vomeronasal non-sensory epithelium (VNSE) of Korean native cattle

\begin{tabular}{|c|c|c|c|c|c|c|c|c|c|c|}
\hline $\begin{array}{c}\text { Lectin } \\
\text { abbreviations }\end{array}$ & \multicolumn{5}{|c|}{ Neonatal structures } & \multicolumn{5}{|c|}{ Adult structures } \\
\hline s-WGA & + & + & - & + & +++ & + & + & - & + & +++ \\
\hline WGA & +++ & ++ & + & ++ & ++ & +++ & ++ & ++ & ++ & +++ \\
\hline LEL & +++ & ++ & + & ++ & +++ & +++ & +++ & +++ & ++ & +++ \\
\hline STL & +++ & + & + & ++ & +++ & +++ & +++ & ++ & ++ & +++ \\
\hline \multicolumn{11}{|c|}{ Mannose-binding lectins } \\
\hline ConA & +++ & ++ & ++ & ++ & ++ & +++ & ++ & ++ & ++ & ++ \\
\hline LCA & - & + & - & - & ++ & + & ++ & + & + & ++ \\
\hline BSL-I & ++ & ++ & - & +++ & ++ & ++ & ++ & - & +++ & ++ \\
\hline VVA & + & ++ & - & - & + & + & +++ & - & - & + \\
\hline DBA & + & + & - & - & - & + & ++ & - & - & + \\
\hline SBA & + & + & - & - & + & + & ++ & - & - & + \\
\hline SJA & + & ++ & + & + & ++ & ++ & ++ & + & + & ++ \\
\hline Jacalin & + & ++ & - & + & + & + & ++ & - & + & + \\
\hline PNA & + & ++ & - & ++ & +++ & ++ & ++ & - & + & +++ \\
\hline ECL & +++ & ++ & + & + & +++ & +++ & +++ & ++ & ++ & +++ \\
\hline \multicolumn{11}{|c|}{ Complex type N-glycans (complex oligosaccharides)-binding lectins } \\
\hline PHA-E & +++ & ++ & + & + & + & +++ & ++ & ++ & + & + \\
\hline
\end{tabular}

-, negative staining; +, faint staining; ++, moderate staining; +++, intense staining.

1985; Adams, 1986; Salazar et al., 1995; Salazar et al., 1997). However, the structural and functional properties of the cattle VNO require further examination. The present study investigated the histology and lectin histochemistry of the VNO in Korean native cattle. First, we confirmed the morphological properties of the VSE and VNSE in the examined VNOs. Like many other mammals, cattle have a well-developed VNO comprising VSE, VNSE, vomeronasal glands, vomeronasal cartilage, and vessels. Histological examination of sections has revealed that bovine vomeronasal glands are ensheathed by hyaline cartilage, which has been observed in other animal species, such as goats (Yang et al., 2021), sheep (Ibrahim et al., 2014), pigs (Salazar et al., 2000), horses (Lee et al., 2003), and camels (Ibrahim et al., 2015).

The VSE of the VNO in Korean native cattle was formed by the prolongations of receptor cells and supporting cells in the superficial layer and scattered basal cells in the basal layer. These defined layers, as well as the neuroepithelium development, are consistent with previous observations in other ungulates, including goats (Yang et al., 2021) and pigs (Park et al., 2012). Consistent with previous studies, nuclei of the vomeronasal basal cells were situated at the basal region of the VSE, while those of the receptor cells were arranged in one or two layers with distinct nucleoli. In addition, nuclei of the supporting cells were situated in the middle region. Vomeronasal basal cells have smaller nuclei than do receptor and supporting cells. Moreover, the VNSE was composed of ciliated cells, basal cells, and goblet cells that were interspersed with ciliated columnar cells. Considering these structural features, it is believed that the VNO in Korean native cattle is also involved in pheromonal information processing, as known in other animals (Dulac and Torello, 2003). Ad- 

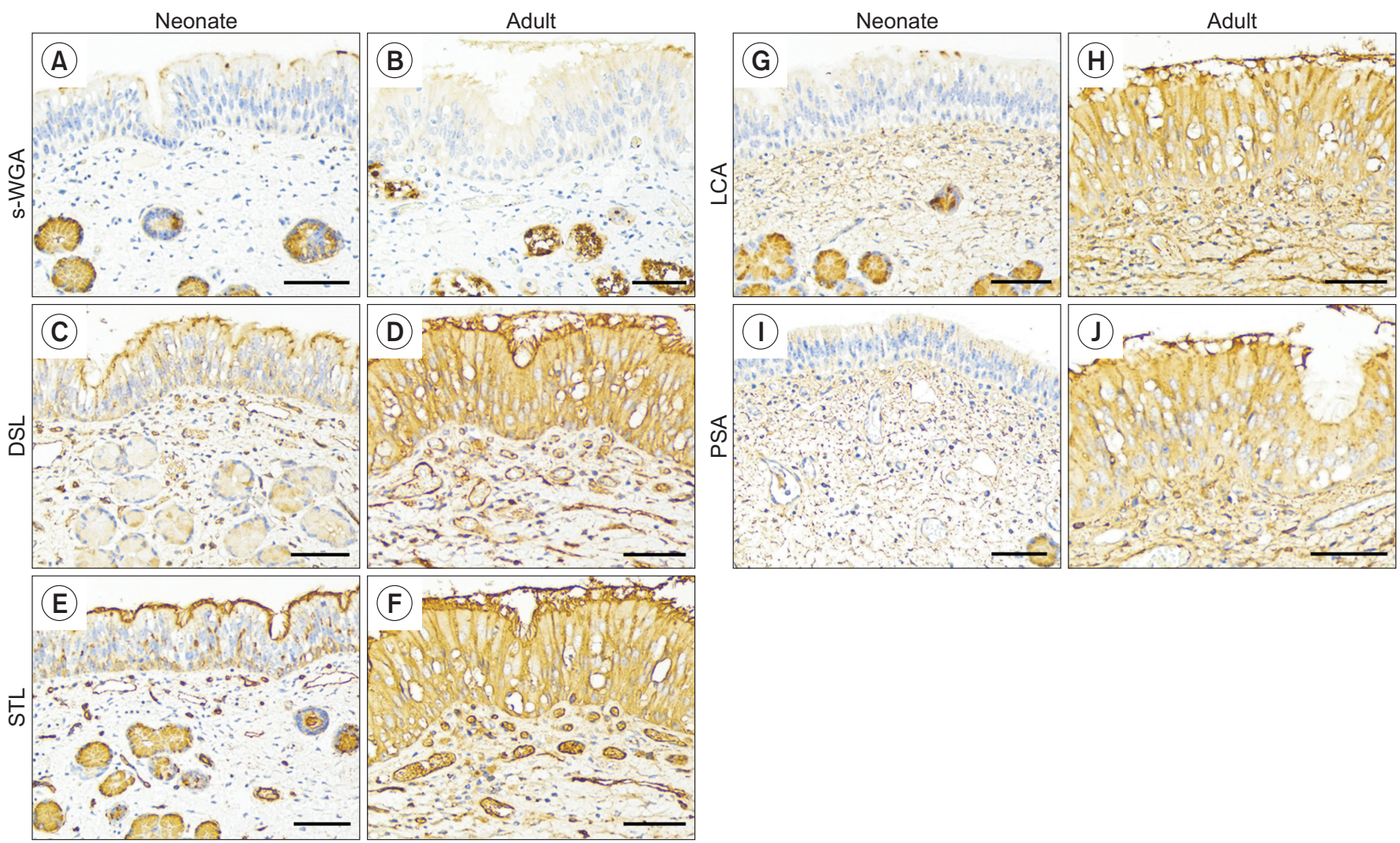

Fig. 6. Lectin histochemistry with $\mathrm{N}$-acetylglucosamine and mannose-binding lectins in the VNSE of Korean native cattle. (A-F) The reactivities of $N$-acetylglucosamine-binding lectins, including S-WGA $(A, B), D S L(C, D)$, and $S T L(E, F)$ in both neonatal $(A, C, E)$ and adult VNSE (B, D, F). G-J: The reactivities of mannose-binding lectins, including LCA $(G, H)$ and PSA (I, J) in both neonatal $(G, I)$ and adult VNSE $(\mathrm{I}, \mathrm{J})$. Counterstained with hematoxylin. DSL, Datura stramonium lectin; LCA, Lens culinaris agglutinin; PSA, Pisum sativum agglutinin; STL, Solanum tuberosum lectin; s-WGA, succinylated-wheat germ agglutinin. Scale bars $=50 \mu \mathrm{m}$.

ditionally, the characteristics identified in the VNO were more clearly distinguished in adults than in neonates. In the present study, the VNOs observed in neonates were functionally incomplete compared to those of adults, despite containing all critical structural components, as postnatal development is required for the organ to be morphologically mature and fully functional (Zancanaro, 2014).

The glandular component of the VNO supplies mucus to the duct, which is necessary for receptor function and molecule entry into the vomeronasal duct. In Korean native cattle, these glands were particularly plentiful in the dorsolateral part of the parenchyma, extending throughout the organ. The mucus coating the sensory epithelium associated with the olfactory system has important qualities since these fluids are known to influence the properties of chemical substances trapped by the epithelium (Khew-Goodall et al., 1991). We defined the glandular secretions in the VNO using PAS and Alcian blue stains.
According to Kondoh et al. (2020), vomeronasal glands in most animal VNOs test positive for PAS, although the responsiveness to Alcian blue staining differs between species. In the present study, both PAS and Alcian blue staining were positive in the glands located beneath the VNSE; however, neonates reacted more strongly to Alcian blue staining than adults. This variability in the intensity of Alcian blue staining between the two age groups is most likely due to the varied nature of the pheromone-receptor interaction (Krishna et al., 1994).

PGP9.5 antibody was used to stain cattle VNOs as a marker of neurons and neuroendocrine cells (Thompson et al., 1983). PGP9.5 immunoreactivities were strongly expressed in neonatal and adult VSEs, as well as in some ciliated cells and nerve fibers in the VNSE. PGP9.5 labeling was observed in most vomeronasal receptor cells in the VSE, but not in the supporting and basal cells. PGP9.5 expression in basal cells of the VSE varies in different animal species. In canine basal cells, the expression is 

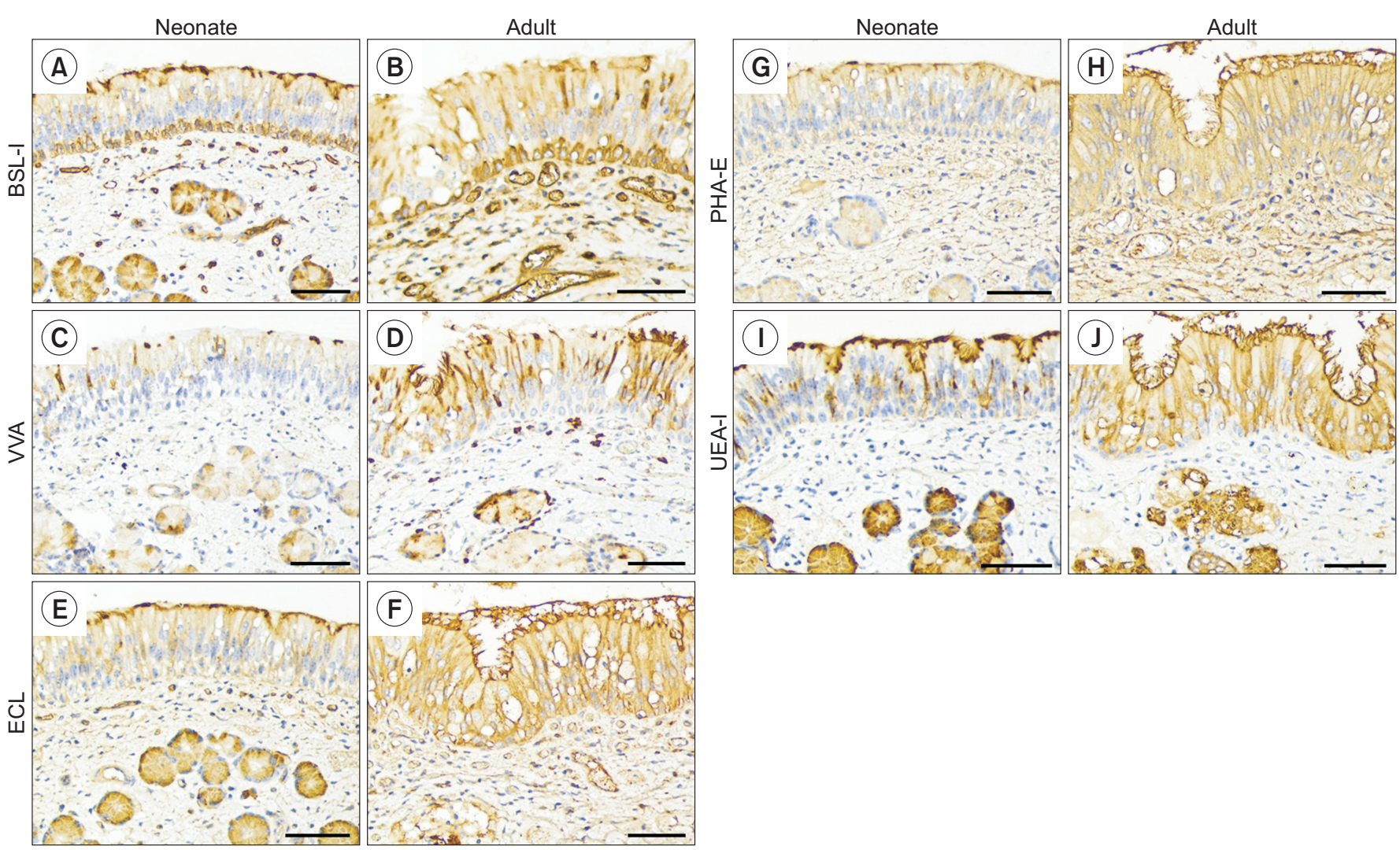

Fig. 7. Lectin histochemistry with galactose/N-acetylgalactosamine, complex type $\mathrm{N}$-glycans (complex oligosaccharides), and fucosebinding lectins in the VNSE of Korean native cattle. (A-F) The reactivities of galactose/ $\mathrm{N}$-acetylgalactosamine-binding lectins, including $B S L-I(A, B), V V A(C, D)$, and $E C L(E, F)$ in both neonatal $(A, C, E)$ and adult VNSE $(B, D, F)$. $(G, H)$ The reactivity of complex type $\mathrm{N}$-glycans-binding lectin PHA-E in both neonatal $(\mathrm{G})$ and adult VNSE $(\mathrm{H}) . \mathrm{I}, \mathrm{J}$ : The reactivity of fucose-binding lectin UEA-I in both neonatal (I) and adult VNSE (J). Counterstained with hematoxylin. BSL-I, Bandeiraea simplicifolia lectin I; ECL, Erythrina cristagalli lectin; PHA-E, Phaseolus vulgaris E, UEA-I, Ulex europaeus I; VVA, Vicia villosa agglutinin. Scale bars $=50 \mu \mathrm{m}$.

not uniform (Dennis et al., 2003), and immunopositivity has been observed in goats (Yang et al., 2021), but not in camels (Ibrahim et al., 2015). Although conditions such as age differ for each animal in these studies, additional studies are needed to clarify the role of PGP9.5 in relation to sensory neurons in VNO.

Additionally, we evaluated OMP expression in the VNO to determine whether it serves as a neuronal marker of terminally differentiated olfactory or vomeronasal receptor neurons (Farbman and Margolis, 1980). OMP expression was diffuse in neonatal VSE, whereas mature receptor cells were clearly positive for OMP in adults. This finding is consistent with the results of earlier studies indicating that OMP expression in the VSE develops postnatally and increases in density and intensity with age, as demonstrated, for instance, in goats (Yang et al., 2021). Some ciliated cells in the VNSE displayed OMP immunoreactivity, which may be related to chemoreception in Korean native cattle. Therefore, PGP9.5 and OMP are critical for olfactory and vomeronasal chemoreception (Bock et al., 2009); however, additional research is required to ascertain their role in sensory neurons in VNO.

Given their membrane interactions, cell-to-cell adhesion, and ion transport capabilities, glycan epitopes may be implicated in pheromone sensing (Spicer and Schulte, 1992). The present study highlighted the precise glycoconjugate localizations in the VNO of Korean native cattle. Lectin histochemistry was identified in the VSE and VNSE cells at varying intensities (Table 3 and 4). Most lectins were expressed in the mucomicrovillous free border of both VSE and VNSE in neonatal and adult cattle, with varying degrees of expression for each lectin. This finding implies that the bulk of the carbohydrates identified by these lectins are found in the mucomicrovillous epithelium of the cattle VNO. In the receptor cells of the VSE, 12 of 21 lectins showed higher expression in adults than in 
neonates. Moreover, 7 lectins in supporting cells and 11 in basal cells displayed higher expression in adults than in neonates. In the VNSE, 10 of 21 lectins in ciliated cells and 6 in goblet cells showed stronger expression in adults than in neonates. There was a clear difference in the expression intensity of glycan epitopes in the VNO between the two age groups of Korean native cattle, despite the fact that our small sample size made it difficult to analyze the expression pattern of glycoconjugates in the VSE and VNSE between neonates and adults. However, the developmental processes differed, which may be clarified by further functional studies.

\section{CONCLUSION}

In conclusion, based on our collective observations of the VNO, the expression patterns of VNO-related proteins and glycoconjugates were significantly different between adult and neonatal VNOs, and the intensities were generally high in adults. These findings may imply that the VNO of adult Korean native cattle exerts a wider range of functions than that of neonates in terms of detecting and responding to the pheromonal cues that are critical for socio-sexual communication. Thus, the data provided support the hypothesis that the Korean native cattle have a highly developed VNO that encompasses a variety of distinct morphological traits. Additionally, these findings may shed light on the role of the VNO and its chemocommunication mechanisms in cattle.

Author Contributions: Conceptualization, S.J., and C.M.; methodology, S.J., B.K., J-S.K., and C.M.; investigation, S.J., B.K., J-S.K., and C.M.; data curation, S.J., B.K., and C.M.; writing-original draft preparation, S.J., and C.M.; writing-review and editing, S.J., and C.M.; supervision, C.M.; project administration, C.M.; funding acquisition, C.M.

\section{Funding: None.}

Ethical Approval: The procedures and protocols followed in the present study were approved by the Institutional Animal Care and Use Committee of Chonnam National University (CNU IACUC-YB-2021-131).

Consent to Participate: Not applicable.
Consent to Publish: Not applicable.

Availability of Data and Materials: Not applicable.

Acknowledgements: None.

Conflicts of Interest: No potential conflict of interest relevant to this article was reported.

\section{REFERENCES}

Adams DR. 1986. The bovine vomeronasal organ. Arch. Histol. Jpn. 49:211-225.

Barrios AW, Núñez G, Sánchez Quinteiro P, Salazar I. 2014. Anatomy, histochemistry, and immunohistochemistry of the olfactory subsystems in mice. Front. Neuroanat. 8:63.

Bock P, Rohn K, Beineke A, Baumgärtner W, Wewetzer K. 2009. Site-specific population dynamics and variable olfactory marker protein expression in the postnatal canine olfactory epithelium. J. Anat. 215:522-535.

Brennan PA and Zufall F. 2006. Pheromonal communication in vertebrates. Nature 444:308-315.

Buiakova OI, Krishna NS, Getchell TV, Margolis FL. 1994. Human and rodent OMP genes: conservation of structural and regulatory motifs and cellular localization. Genomics 20:452-462.

D’Oliveira Albanus R, Siqueira Dalmolin RJ, Rybarczyk-Filho JL, Alves Castro MA, Fonseca Moreira JC. 2014. Differential evolutionary constraints in the evolution of chemoreceptors: a murine and human case study. ScientificWorldJournal 2014:696485.

Dennis JC, Allgier JG, Desouza LS, Eward WC, Morrison EE. 2003. Immunohistochemistry of the canine vomeronasal organ. J. Anat. 203:329-338.

Dennis JC, Smith TD, Bhatnagar KP, Bonar CJ, Burrows AM, Morrison EE. 2004. Expression of neuron-specific markers by the vomeronasal neuroepithelium in six species of primates. Anat. Rec. A Discov. Mol. Cell. Evol. Biol. 281:11901200.

Dulac C and Torello AT. 2003. Molecular detection of pheromone signals in mammals: from genes to behaviour. Nat. Rev. Neurosci. 4:551-562.

Farbman AI and Margolis FL. 1980. Olfactory marker protein during ontogeny: immunohistochemical localization. Dev. Biol. 74:205-215.

Firestein S. 2001. How the olfactory system makes sense of scents. Nature 413:211-218.

Gorelik E, Galili U, Raz A. 2001. On the role of cell surface carbohydrates and their binding proteins (lectins) in tumor metastasis. Cancer Metastasis Rev. 20:245-277.

Grus WE and Zhang J. 2004. Rapid turnover and species-specificity of vomeronasal pheromone receptor genes in mice and rats. Gene 340:303-312. 
Halpern M. 1987. The organization and function of the vomeronasal system. Annu. Rev. Neurosci. 10:325-362.

Ibrahim D, Abdel-Maksoud F, Taniguchi K, Yamamoto Y, Taniguchi K, Nakamuta N. 2015. Immunohistochemical studies for the neuronal elements in the vomeronasal organ of the one-humped camel. J. Vet. Med. Sci. 77:241-245.

Ibrahim D, Nakamuta N, Taniguchi K, Yamamoto Y, Taniguchi K. 2014. Histological and lectin histochemical studies on the olfactory and respiratory mucosae of the sheep. J. Vet. Med. Sci. 76:339-346.

Johnson EW, Eller PM, Jafek BW. 1995. Distribution of OMP-, PGP 9.5- and CaBP-like immunoreactive chemoreceptor neurons in the developing human olfactory epithelium. Anat. Embryol. (Berl.) 191:311-317.

Kang J, Park C, Jang Y, Ahn M, Shin T. 2016. Lectin histochemistry of Kudoa septempunctata genotype ST3-infected muscle of olive flounder (Paralichthys olivaceus). Parasite 23:21.

Kelliher KR. 2007. The combined role of the main olfactory and vomeronasal systems in social communication in mammals. Horm. Behav. 52:561-570.

Keverne EB. 2005. Odor here, odor there: chemosensation and reproductive function. Nat. Neurosci. 8:1637-1638.

Khew-Goodall Y, Grillo M, Getchell ML, Danho W, Getchell TV, Margolis FL. 1991. Vomeromodulin, a putative pheromone transporter: cloning, characterization, and cellular localization of a novel glycoprotein of lateral nasal gland. FASEB J. 5:2976-2982.

Kondoh D, Tomiyasu J, Itakura R, Sugahara M, Yanagawa M, Watanabe K, Alviola PA, Yap SA, Cosico EA, Cruz FA, Larona AR, Manalad AJF, Masangkay JS, Sugiura Y, Kyuwa S, Watanabe S, Une Y, Omatsu T, Bando H, Kato K. 2020. Comparative histological studies on properties of polysaccharides secreted by vomeronasal glands of eight Laurasiatheria species. Acta Histochem. 122:151515.

Krishna NS, Getchell ML, Getchell TV. 1994. Expression of the putative pheromone and odorant transporter vomeromodulin mRNA and protein in nasal chemosensory mucosae. J. Neurosci. Res. 39:243-259.

Lam SK and Ng TB. 2011. Lectins: production and practical applications. Appl. Microbiol. Biotechnol. 89:45-55.

Lee JY, Kang TY, Lee YD, Shin TK. 2003. Histochemical characterization of the lectin-binding sites in the equine vomeronasal organ. J. Vet. Sci. 4:15-19.

Lee KH, Park C, Bang H, Ahn M, Moon C, Kim S, Shin T. 2016. Histochemical study of the olfactory mucosae of the horse. Acta Histochem. 118:361-368.

Lin W, Ezekwe EA Jr, Zhao Z, Liman ER, Restrepo D. 2008. TRPM5-expressing microvillous cells in the main olfactory epithelium. BMC Neurosci. 9:114.

Lledo PM, Gheusi G, Vincent JD. 2005. Information processing in the mammalian olfactory system. Physiol. Rev. 85:281317.

Martín-Sánchez A, McLean L, Beynon RJ, Hurst JL, Ayala G, Lanuza E, Martínez-Garcia F. 2015. From sexual attraction to maternal aggression: when pheromones change their be- havioural significance. Horm. Behav. 68:65-76.

Meisami E and Bhatnagar KP. 1998. Structure and diversity in mammalian accessory olfactory bulb. Microsc. Res. Tech. 43:476-499.

Mendoza AS and Kühnel W. 1991. [Lectin histochemistry on the olfactory region and the vomeronasal organ or rats and golden hamsters]. Acta Histochem. 91:173-184. German.

Minett FC. 1925. The organ of Jacobson in the horse, ox, camel and pig. J. Anat. 60(Pt 1):110-118.

Nakajima T, Shiratori K, Ogawa K, Tanioka Y, Taniguchi K. 1998. Lectin-binding patterns in the olfactory epithelium and vomeronasal organ of the common marmoset. J. Vet. Med. Sci. 60:1005-1011.

Ortiz-Leal I, Torres MV, Villamayor PR, López-Beceiro A, Sanchez-Quinteiro P. 2020. The vomeronasal organ of wild canids: the fox (Vulpes vulpes) as a model. J. Anat. 237:890906.

Park C, Ahn M, Lee JY, Lee S, Yun Y, Lim YK, Taniguchi K, Shin T. 2014. A morphological study of the vomeronasal organ and the accessory olfactory bulb in the Korean roe deer, Capreolus pygargus. Acta Histochem. 116:258-264.

Park C, Choi S, Joo HG, Ahn M, Taniguchi K, Shin T. 2012. Galectin-3 immunohistochemistry in the vomeronasal organ of the domestic pig, Sus scrofa. Acta Histochem. 114:713-718.

Plendl J and Sinowatz F. 1998. Glycobiology of the olfactory system. Acta Anat. (Basel) 161:234-253.

Salazar I and Quinteiro PS. 2009. The risk of extrapolation in neuroanatomy: the case of the Mammalian vomeronasal system. Front. Neuroanat. 3:22.

Salazar I, Quinteiro PS, Cifuentes JM. 1997. The soft-tissue components of the vomeronasal organ in pigs, cows and horses. Anat. Histol. Embryol. 26:179-186.

Salazar I, Sánchez-Quinteiro P, Alemañ N, Prieto D. 2008. Anatomical, immnunohistochemical and physiological characteristics of the vomeronasal vessels in cows and their possible role in vomeronasal reception. J. Anat. 212:686-696.

Salazar I, Sánchez Quinteiro P, Lombardero M, Aleman N, Fernández de Trocóniz P. 2004. The prenatal maturity of the accessory olfactory bulb in pigs. Chem. Senses 29:3-11.

Salazar I, Sanchez-Quinteiro P, Lombardero M, Cifuentes JM. 2000. A descriptive and comparative lectin histochemical study of the vomeronasal system in pigs and sheep. J. Anat. 196(Pt 1):15-22.

Salazar I, Sánchez Quinteiro P, Lombardero M, Cifuentes JM. 2001. Histochemical identification of carbohydrate moieties in the accessory olfactory bulb of the mouse using a panel of lectins. Chem. Senses 26:645-652.

Salazar I, Sánchez Quinteiro PS, Cifuentes JM. 1995. Comparative anatomy of the vomeronasal cartilage in mammals: mink, cat, dog, pig, cow and horse. Ann. Anat. 177:475-481.

Sharon N and Lis H. 2004. History of lectins: from hemagglutinins to biological recognition molecules. Glycobiology 14:53R-62R.

Silva L and Antunes A. 2017. Vomeronasal receptors in vertebrates and the evolution of pheromone detection. Annu. 
Rev. Anim. Biosci. 5:353-370.

Spicer SS and Schulte BA. 1992. Diversity of cell glycoconjugates shown histochemically: a perspective. J. Histochem. Cytochem. 40:1-38.

Taniguchi K and Mikami S. 1985. Fine structure of the epithelia of the vomeronasal organ of horse and cattle. A comparative study. Cell Tissue Res. 240:41-48.

Thompson RJ, Doran JF, Jackson P, Dhillon AP, Rode J. 1983. PGP 9.5--a new marker for vertebrate neurons and neuroendocrine cells. Brain Res. 278:224-228.

Villamayor PR, Cifuentes JM, Fdz-de-Troconiz P, SanchezQuinteiro P. 2018. Morphological and immunohistochemical study of the rabbit vomeronasal organ. J. Anat. 233:814827.
Wormald MR and Sharon N. 2004. Carbohydrates and glycoconjugates: progress in non-mammalian glycosylation, glycosyltransferases, invertebrate lectins and carbohydratecarbohydrate interactions. Curr. Opin. Struct. Biol. 14:591592.

Yang W, Choi Y, Park C, Lee KH, Ahn M, Kang W, Heo SD, Kim J, Shin T. 2021. Histological and lectin histochemical studies in the vomeronasal organ of the Korean black goat, Capra hircus coreanae. Acta Histochem. 123:151684.

Zancanaro C. 2014. Vomeronasal organ: a short history of discovery and an account of development and morphology in the mouse. In: Mucignat-Caretta C (Ed.), Neurobiology of Chemical Communication, CRC Press, Boca Raton, pp. 285296. 